\title{
Water absorption process capability analysis by chicken carcasses during precooling
}

\author{
Elidiane LORENZETTI ${ }^{1,2}$, Bruna Maria Saorin PUTON ${ }^{1}$, Juliana STEFFENS ${ }^{1}$, Alexander JUNGES ${ }^{1}$, \\ Natalia PAROUL ${ }^{1}$, Geciane Toniazzo BACKES ${ }^{1}$, Eunice VALDUGA ${ }^{1}$, Rogério Luis CANSIAN ${ }^{1 *}$
}

\begin{abstract}
Cooling of carcasses using water immersion is the most used process in the poultry industry. In this stage, besides the reduction of temperature, water absorption in the carcasses occurs and, consequently, in the chicken cuts, which are monitored by the companies and supervised by the Ministry of Agriculture, Livestock, and Supply of Brazil, which establishes water absorption limits. The objective of this work was to evaluate the process capacity analysis tool to analyze the water absorption capacity by chicken carcasses during precooling, based on the absorption indexes obtained on an industrial scale, by the analysis of 720 carcasses. After structural alterations, aiming at greater bubble control and shorter residence time of the chicken carcasses in the cooling system, $\mathrm{Cp}$ (process potential index) and $\mathrm{Cpk}$ (process performance index) were close to each other $(0.82$ and 0.81 , respectively), indicating that the process is practically centralized and, although it has become smaller than 1, presented a significant improvement over the initial evaluation (cp 0.35 and cpk 0.26).
\end{abstract}

Keywords: process potential index; process performance index; chicken carcasses; water absorption; chiller.

Practical Application: The control of water absorption in the cooling process of chicken carcasses is a great concern of the companies, because possible deviations can result in excessive absorption of water by chicken carcasses, above the limits indicated in the legislation.

\section{Introduction}

Among the operations involved in the processing of chicken meat, cooling is considered one of the most important stages. Temperature reduction controls microbial growth and influences the main indicators of meat quality, such as flavor, appearance and texture (Savell et al., 2005; Nagyová et al., 2016), so adequate cooling is a requirement of national and international laws (Carciofi \& Laurindo, 2010). This operation is carried out in semi-cylindrical tanks (chillers), equipped with an internal helicoid that moves slowly, promoting the displacement of the carcasses. The chicken carcasses are immersed and transported in a mixture of water and ice, being cooled from approximately $40{ }^{\circ} \mathrm{C}$ to $4{ }^{\circ} \mathrm{C}$ (measured at the center of the pectoralis muscle) at the exit of the equipment (Carciofi \& Laurindo, 2007; Carciofi \& Laurindo, 2010; Rodrigues et al., 2015). It is during this stage that water absorption occurs through the chicken carcasses (Scaratti et al., 2016).

The control of the water absorption index is performed through two official methods: the internal control method that is performed at the industrial processing level and treats the absorbed water during the pre-cooling by immersion; and the dripping test that quantifies the water coming from the defrosting of frozen carcasses. The results are expressed as a percentage of the total weight of the carcass, with the maximum limits of $8 \%$ and 6\%, respectively (Brasil, 1998; Brasil, 1999).
Many factors affect water absorption by the carcasses, and the most important are water temperature, time that carcasses remain in the chiller, proportion of water and ice in the tank, agitation (bubbling), carcass size, and thickness of skin and fat (Katz \& Dawson, 1964).

Standardization plays an important role in the control and improvement of quality in companies, by contributing to the reduction of the variability of production processes (Polo-Redondo \& Cambra-Fierro, 2008; Rábago-Remy et al., 2014; Arcidiacono \& Nuzzi, 2017). It is the standardization process that supports the uniformity of value-adding activities and provides continuous improvement in the production system, since it is based on a set of systematic activities that establishes, uses, and evaluates standards in relation to their performance, their adequacy and its effects on the results (Cavanha Filho, 2006).

In quality control of industrial processes, it is common to use tools and statistical techniques for monitoring, controlling, or improving production processes. However, the literature shows that, for some organizations, mostly large, the potential of statistics goes beyond this operational link to seek continuous improvement, since it allows other competitive advantages resulting from the products and processes quality assurance (Santos \& Antonelli, 2011). One of the statistical tools used to evaluate if a process is operating within the ideal projected specifications, is the process capability analysis.

${ }^{1}$ Departamento de Engenharia de Alimentos, Universidade Regional Integrada do Alto Uruguai e das Missões, URI - Campus de Erechim, Erechim, RS, Brasil

${ }^{2}$ BRF - Brasil Foods S.A., Dois Vizinhos, PR, Brasil

*Corresponding author: cansian@uricer.edu.br 
The first capacity indices developed were $\mathrm{Cp}$, called potential capacity index of the process, and Cpk performance index of the process, which are the most used in the industry. The advantage of using these indices is that they are dimensionless, facilitating the comparison of productive processes, regardless of what is being produced (Oliveira et al., 2011; Rábago-Remy et al., 2014; Arcidiacono \& Nuzzi, 2017).

However, there are few reports in the scientific literature about the effectiveness of the use of these tools in food industries. To our knowledge, there are no studies reporting the use of this tool to evaluate the performance of improvements in the process of cooling chicken carcasses in order to comply with the legislation regarding water absorption. In this sense, the objective of this work was to evaluate the process capacity analysis tool to analyze the water absorption capacity by chicken carcasses during precooling, based on the absorption indexes obtained on an industrial scale, by the analysis of 720 carcasses.

\section{Material and methods}

The present study was carried out in a poultry slaughterhouse under federal inspection located in the south of Brazil, whose slaughtering capacity is approximately 720,000 birds/day.

The precooling process of chicken carcasses consists of three chillers in series, all with diameters of $3 \mathrm{~m}$. In the slaughter line where the data were collected, the first module (pre-chiller) is $6 \mathrm{~m}$ long, the second module (chiller 1 ) is $8 \mathrm{~m}$, and the third module (chiller 2) is $8 \mathrm{~m}$. The speed rotation of each module of the precooling system (pre-chiller, chiller 1, and chiller 2) varies from 20 to $60 \mathrm{~Hz}$ in each module. This speed is dimensioned for a residence time of the carcasses that can vary from 10 to $30 \mathrm{~min}$ in each module.

A total of 720 chicken carcasses were collected to evaluate the current situation of the percentage of water absorption. Samples were randomly collected over a period of approximately two months and they comprise different days and times of production.

The carcasses were collected after the final showers, at the entrance of the pre-cooling system and before they go to the pre-chiller. After were placed in plastic boxes and received a tape containing an identification number and were weighed individually $\left(\mathrm{P}_{1}\right)$.

After this, the carcasses were placed at the beginning of the first stage of the pre-chiller system, and the start time test was recorded. Subsequently, the water temperatures of pre-chiller, chiller 1 , and chiller 2 , were verified and recorded. The presence, or not, of bubbles was also verified at each stage and the total residence time of the carcasses in the precooling system.

When the carcasses exited the chiller 2 they passed through a rotating sieve, which aims to remove excess water accumulated under the skin and temperature of the carcasses was measured. After this step, the carcasses were manually regrinded by one of the legs, to drip and transport to the packaging. Subsequently, the carcasses were weighed again $\left(\mathrm{P}_{2}\right)$.

Water absorption was calculated following the Brazilian Ordinance n 210/1998 (Brasil, 1998).
In this work, the following variables were kept fixed: weight of the carcasses (1000 to $1100 \mathrm{~g}$ ), slaughter speed (12,500 birds/h), temperature of the water heating tank $1\left(52^{\circ} \mathrm{C} \pm 1\right)$ and tank 2 $\left(62{ }^{\circ} \mathrm{C} \pm 1\right)$, feather removal temperature $\left(60^{\circ} \mathrm{C} \pm 1\right)$, temperature of carcasses at the entrance of pre-cooling system $\left(35^{\circ} \mathrm{C} \pm 3^{\circ} \mathrm{C}\right)$, pre-chiller water temperature $\left(6^{\circ} \mathrm{C} \pm 1\right)$, water temperature of chiller $1\left(2{ }^{\circ} \mathrm{C} \pm 1\right)$ and chiller $2\left(1^{\circ} \mathrm{C} \pm 1\right)$, drip time (minimum $1 \mathrm{~min}$ and $23 \mathrm{~s}$ and maximum $2 \mathrm{~min}$ and $23 \mathrm{~s}$ ) and integrity of carcasses (without cuts or bruises).

With the absorption indexes obtained through the collections, the capacity of the process of water absorption by the chicken carcasses during the precooling stage was carried out. The results were submitted to capacity analysis using Minitab software version 17.

\section{Results and discussion}

The evaluation of variables on the process of water absorption by the chicken carcasses during the precooling stage was carried out in order to evaluate the variability of the process under study. Analyzing the capacity histogram of the absorption process shown in Figure 1.

A lower specification limit (LSL) was defined for absorption results of at least $5 \%$ and an upper specification limit (USL) for absorption results up to $8 \%$. This is because results below $5 \%$ represent a decrease in profitability and results above $8 \%$ are in violation of the current national legislation (Brasil, 1998). Variability in absorption results was observed, where $34.17 \%$ of the results showed absorption below $5 \%$ or above $8 \%$. In this case, where individual carcasses were evaluated, $11.53 \%$ of the carcasses have the percentage of water absorption above the limit allowed by the legislation, which is $8 \%$.

The evaluation of the process's ability to meet the established specifications is measured by the relationship between the natural variability of the process in relation to the variability that is allowed to that process, given by the specification limits. For this, dimensionless indices are used, which allows for quantification of the performance of processes that are $\mathrm{Cp}$ (potential process

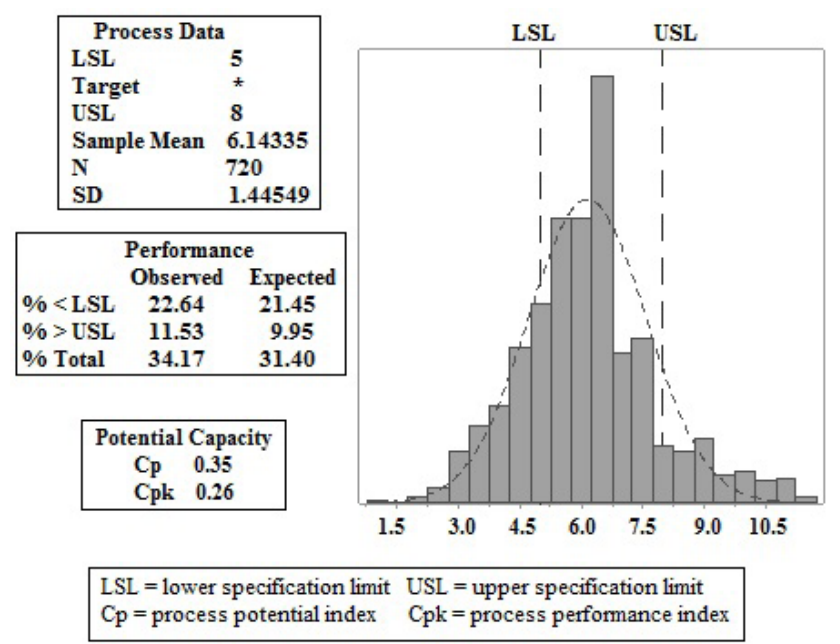

Figure 1. Water absorption process capability with all samples of chicken carcasses. 
capability index) and Cpk (process performance index) (Gonçalez \& Werner, 2009; Montgomery, 2009; Rábago-Remy et al., 2014; Arcidiacono \& Nuzzi, 2017).

Since Cp (0.35) was different from Cpk (0.26), the process was not centered on the midpoint of the specifications. In these cases, the use of Cp index can lead to erroneous conclusions, where the Cpk performance index is used, which takes into account the distance of the process average from specification limits (Gonçalez \& Werner, 2009).

To analyze the Cp index, Montgomery (2009) defines three reference ranges: $\mathrm{Cp}$ or $\mathrm{Cpk}<1$, the process is considered to be incapable; $\mathrm{Cp}$ or $\mathrm{Cpk} \geq 1$ or $\leq 1.33$, the process is acceptable, and for $\mathrm{Cp}$ or $\mathrm{Cpk} \geq 1.33$, the process is potentially capable. In general, the higher the $\mathrm{Cp}$, the more capable the process is. Thus, it is assumed that the pre-cooling process is incapable in relation to the water absorption because it presented a Cpk value much lower than 1.0.

Although the precooling process of chicken carcasses is considered incapable, according to the analysis of the capacity obtained through the absorption indexes, the control performed by both the company and the Federal Inspection System, guarantee the attendance of the percentage of absorption within of the maximum allowed limit of $8 \%$, where the mean values of absorption are considered.

According to the PPCAWP (Program for Prevention and Control of Addition of Water to Products), carried out based on Ordinance no 210/1998 (Brasil, 1998), each absorption test consists of 12 carcasses where the percentage of absorption is the average of the 12 carcasses. Thus, it can be verified that no test was above the specified upper limit (LSE) of $8 \%$ (Figure 2).

However, the incidence of out-of-standard results may risk absorbing results above the allowable limit. Thus, the need to reduce this variability of the process was verified and, through the control parameters, to work with a percentage of absorption that aims at profitability, but that meets the legal requirements.

A great variability in the retention times of carcasses was verified in the chillers, showing that there are points at which they do not follow the process flow. These points were verified in loco. This difference causes variations in the percentage of water absorbed by the carcasses. Figure 3 shows a frequency histogram for residence time of chicken carcasses in the precooling system.

In agreement with the observed in this study, Carciofi (2005) reported that one of the factors which affect the water absorption process is the low mobility of the carcasses in the device (chiller). Besides the difficulty of water circulation and the reduction of contact area, the presence of chicken carcasses at different levels of depth promotes differences in the percentage of water absorbed by the carcasses.

Points were verified in the precooling system of carcasses that had a direct impact on the distribution and intensity of the bubbles and, especially on the residence time of carcasses in the pre-chiller and chillers.

Among these points, the bad positioning of the bubble hoses was verified, lack of a manometer for adjusting and measuring

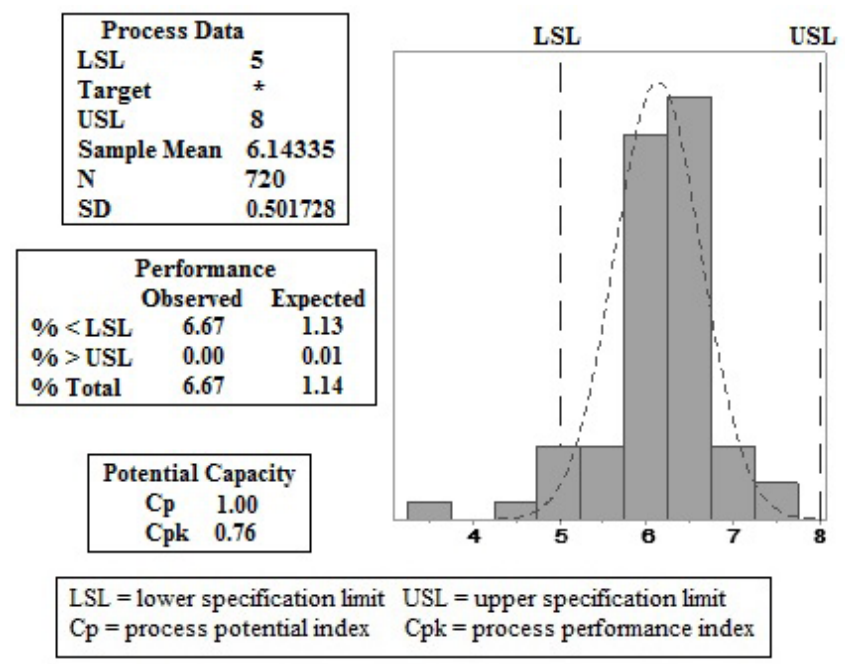

Figure 2. Water absorption process capability with the average of chicken carcass samples according to Ordinance nº 210/1998.

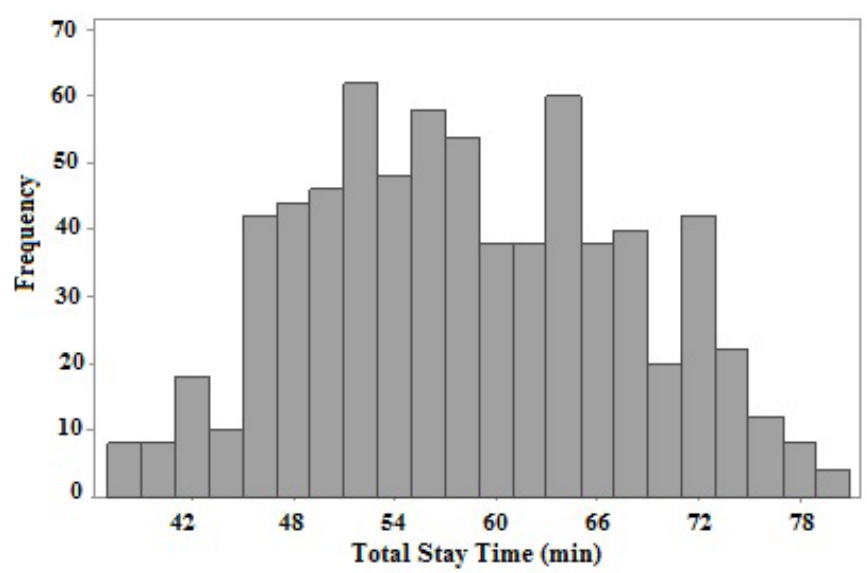

Figure 3. Histogram of frequency of total stay time of chicken carcasses in the pre-cooling system.

the intensity of the bubbles used (pressure), the distance between the pre-chiller and chillers helicoids, and the existence of "empty" points at the entrance and exit of chiller 1 and chiller 2 .

To improve the distribution of the bubbles the repositioning of the hoses in the cooling tanks was performed, where part of the air inlets were closed and gauges were installed to control the intensity of the bubbles injected in the precooling system. The reduction of the distance between pre-chiller and chillers helicoids, and the elimination of the empty points at the entrance and exit of the chillers 1 and 2 was made from the installation of stainless steel plates. The water level of all cooling tanks has also been reduced up to the height of the shaft.

The structural adaptations helped to guide the carcasses, preventing them from being stopped at some point in the chillers, trapped in the void spaces, or returned over the axis, allowing flow along the precooling system and therefore reducing the dispersion time between the carcasses. 
The pre-chiller, chiller 1, chiller 2, and chiller average water temperatures of the precooling system were $3.9,1.7,0.8$, and $4.5^{\circ} \mathrm{C}$, respectively, which are within the maximum limits allowed by Ordinance $\mathrm{n}^{\circ} 210 / 1998$ which is $16^{\circ} \mathrm{C}$ for the pre-chiller, $4^{\circ} \mathrm{C}$ for the chillers, and $7^{\circ} \mathrm{C}$ for the exit of the chiller (Brasil, 1998).

The temperature control was performed by rechillers. This system allows for a more accurate temperature control when compared to ice cooling, thus ensuring the stability and homogeneity of water temperature of the precooling system. It was observed that all the evaluated carcasses had temperatures below $7{ }^{\circ} \mathrm{C}$ at the chiller outlet, evidencing that the company has adequate control of the cooling process.

After structural adaptations in the equipment of the precooling system, a new analysis of the capacity of the process of water absorption by chicken carcasses was carried out.

Figure 4 presents the analysis of the capacity of water absorption process by chicken carcasses after the structural adjustments and the standardization of the variables through the experimental design.

Considering LSL of $5 \%$ and USL of $8 \%$, it is observed that all the results evaluated were within this specification (Figure 4A). The results of $\mathrm{Cp}$ and $\mathrm{Cpk}$ showed results greater than 1.33 (2.45 and 2.44, respectively), showing that the process
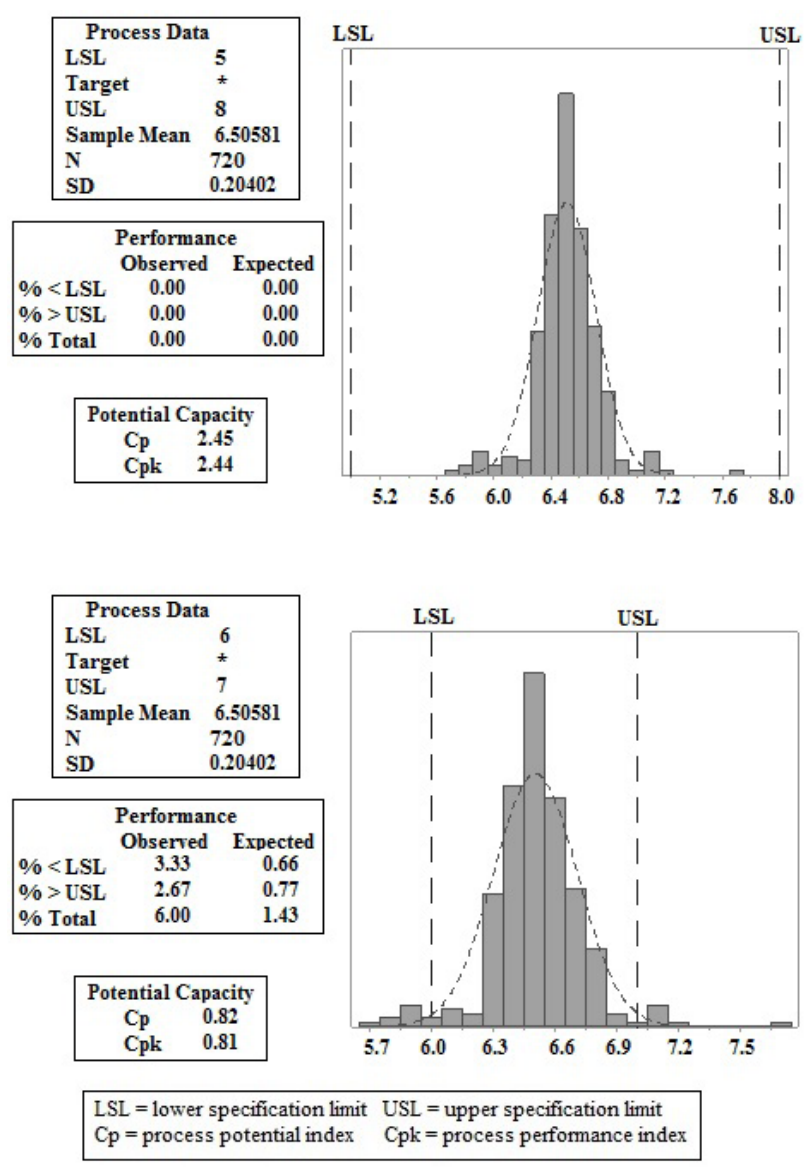

Figure 4. Water absorption process capability analysis with all the samples of chicken carcasses after the structural adjustments in pre-cooling system LSL 5\% and USL 8\% (A), and 6\% LSL and USL 7\% (B). is potentially capable. When compared to Figure 1, which was generated from the initial collections of this study, there was a significant evolution in the process of water absorption by chicken carcasses.

In order to increase profitability and reduce risks of violation of the current national legislation (Brasil, 1998), the lower limit of resulting absorption was defined as at least $6 \%$ and the upper limit of resulting absorption to be up to $7 \%$. As can be seen in Figure $4 \mathrm{~B}$, only $6 \%$ of the results were below $6 \%$ or above $7 \%$ of water absorption, showing the stability of the process. This variation can be considered normal, since other factors may interfere on the process of water absorption by chicken carcasses, even with a lesser impact, such as carcass quality.

The Cp (process potential index) and Cpk (process performance index) were close to each other ( 0.82 and 0.81 , respectively) indicating that the process, after adjustments, is practically centralized and, although were less than 1 , showed a significant improvement over the initial evaluation (Cp 0.35 and Cpk 0.26) with LSL $6 \%$ and USL $7 \%$. This change in process capacity indexes confirms a significant evolution in the process of water absorption by chicken carcasses. It is noteworthy that all results were within the limits allowed by the legislation.

\section{Conclusion}

The process capacity analysis was shown to be an effective statistical tool in the diagnosis of changes in the water absorption process in chicken carcasses. The Cp (process potential index) and Cpk (process performance index) of 0.82 and 0.81 or 2.45 and 2.44 , for LSL and USL of 5 and $8 \%$ or 6 and $7 \%$, respectively, presented significant improvement over the initial evaluation ( 0.35 and 0.26 for LSL and USL of 5 and $8 \%$, respectively). Structural alterations, aiming at greater bubble control and shorter residence time of the chicken carcasses in the cooling system, were sufficient to standardize the process of water absorption.

\section{Acknowledgements}

The authors would like to thank Cnpq, Capes (Coordenação de Aperfeiçoamento de Pessoal de Nível Superior), Fapergs and URI for their financial support.

\section{References}

Arcidiacono, G., \& Nuzzi, S. (2017). A review of the fundamentals on process capability, process performance, and process sigma, and an introduction to process sigma split. International Journal of Applied Engineering Research, 12(14), 4556-4570.

Brasil, Ministério da Agricultura e do Abastecimento. Secretaria de Defesa Agropecuária. (1998, November 10). Regulamento técnico da inspeção tecnológica e higiênico-sanitáriade carne de aves (Portaria no 210 , de 10 de novembro de 1998). Diário Oficial [da] República Federativa do Brasil.

Brasil, Ministério da Agricultura, Pecuária e Abastecimento. Secretaria de Defesa Agropecuária. (1999, Julho 21). Instrução Normativa nº 20, de 21 de julho de 1999. Métodos analíticos físico-químicos para controle de produtos cárneos e seus ingredientes - sal e salmoura. Diário Oficial [da] República Federativa do Brasil. 
Carciofi, B. A. M. (2005). Estudo do resfriamento de carcaças de frango em chiller de imersão em água (MSc thesis). Universidade Federal de Santa Catarina, Florianópolis.

Carciofi, B. A. M., \& Laurindo, J. B. (2007). Water uptake by poultry carcasses during cooling by water immersion. Chemical Engineering and Processing, 46, 444-450.

Carciofi, B. A. M., \& Laurindo, J. B. (2010). Experimental results and modeling of poultry carcass cooling by water immersion. Food Science and Technology, 30(2), 447-453.

Cavanha Filho, A. O. (2006). Estratégia de compras. Rio de Janeiro: Editora Ciência Moderna.

Gonçalez, P. U., \& Werner, L. (2009). Comparação dos índices de capacidade do processo para distribuições não-normais. Gestão \& Produção, 16(1), 121-132.

Katz, M., \& Dawson, L. E. (1964). Water absortion and retention by cut up broiler parts chilled in polyphosphate solutions. Poultry Science, 43, 1541-1546.

Montgomery, D. C. (2009). Introduction to statistical quality control (6th ed.). New York: John Wiley \& Sons.

Nagyová, A., Korim, P., Mellen, M., Nagy, J., Popelka, P., \& Pipová, M. (2016). The efficacy of air spray chilling and its impact on microbial quality of broiler carcasses. Italian Journal of Animal Science, 14, 120-123.

Oliveira, J. B., Souto, R. R., Maia, R. D. A., Meira, J. A., \& Lima, V. S. P. (2011, Outubro04-07). Análise da capacidade de um processo: um estudo de caso baseado nos indicadores Cp e Cpk. In Associação Brasileira de Engenharia de Produção - ABEPRO. Inovação tecnológica e propriedade intelectual: Desafios da Engenharia de Produção na consolidação do Brasil no Cenário Econômico Mundial, Belo Horizonte, Minas Gerais: ABEPRO.

Polo-Redondo, Y., \& Cambra-Fierro, J. (2008). Influence of the standardization of a firm's productive process on the long-term orientation of its supply relationships: An empirical study. Industrial Marketing Management, 37(4), 407-420.

Rábago-Remy, D. M., Edith Padilla-Gasca, E., \& Rangel-Peraza, J. G. (2014). Statistical quality control and process capability analysis for variability reduction of the tomato paste filling process. Industrial Engineering \& Management, 3(4), e137.

Rodrigues, L. G. G., Carciofi, B. A. M., \& Laurindo, J. B. (2015). Poultry carcasses chilled by forced air, water immersion and combination of forced air and water immersion. Journal of Food Process Engineering, 37, 550-559.

Santos, A. B., \& Antonelli, S. C. (2011). Aplicação da abordagem estatística no contexto da gestão da qualidade: um survey com indústrias de alimentos de São Paulo. Gestão \& Produção, 18(3), 509-524.

Savell, J. W., Mueller, S. L., \& Baird, B. E. (2005). The chilling of carcasses. Meat Science, 70(3), 449-459. PMid:22063744.

Scaratti, D., Geremias, R., Franchin, P. R., \& Scaratti, G. (2016). Determination of moisture levels, protein and water absorption of chicken giblets. Brazilian Journal of Poutry Science, 18(1), 193-196. 